AKRUAL 2 (2) (2011): 172-199 $e$-ISSN: 2502-6380

\title{
AKRUAL
}

Jurnal Akuntansi

http://fe.unesa.ac.id/ojs/index.php/akrl

\section{PENGARUH TRANSPARANSI DAN AKUNTABILITAS TERHADAP PENGUMPULAN DANA ZAKAT, INFAQ DAN SHODAQOH PADA LAZ DI SURABAYA}

\author{
Dina Fitrisia Septiarini \\ Fakultas Ekonomi dan Bisnis Universitas Airlangga \\ Email: dina.fitrisia@gmail.com
}

Artikel diterima: 10 Desember 2010

Revisi terakhir: 5 Februari 2011

\begin{abstract}
Potential acceptance of zakat in Indonesia is very large, considering Indonesia is a country with the largest Muslim population in the world. Potential new revenue forecast comes from the charity, not including potential revenues derived from infaq and shodaqoh and endowments. Zakat earnings potential is still far from reality receiving alms, infaq and shodaqoh, acceptance of zakat in Indonesia in 2009 amounted to Rp. 250 billion or just $0.13 \%$ of the existing potential of zakat. Zakat also serves as worship that bridges the rich and the poor in order to avoid extreme disparities. In the Qur'an itself there are 27 verses that align with the obligation of zakat obligations prayer. This study uses quantitative methods by taking the population is the Muzakki the zakat funds, infaq and shodaqoh through the Amil Zakat Foundation (LAZ) in Surabaya while the sample used is the Muzakki from 5 LAZ raised in Surabaya by 75 respondents. Using Multiple Regression analysis with SPSS. The results showed that there is a positive correlation or there is the influence of sermons and the mandate of charity fundraising, and shodaqoh infaq on LAZ in Surabaya.
\end{abstract}

Key words: Transparancy, Tabligh, Accountability, Amanah, ZIS Funds

\section{PENDAHULUAN}

\section{Latar Belakang}

Salah satu faktor penyebab tidak tercapainya potensi penerimaan zakat di Indonesia adalah keputusan para muzaki untuk tidak menyalurkan zakat, infaq dan shodaqoh pada organisasi pengelola zakat yang ada adalah faktor kepercayaan yang masih rendah pada organisasi tersebut sehingga menyebabkan para muzaki lebih memilih untuk menyalurkan dana zakatnya secara langsung kepada mereka yang berhak atau 8 asnaf. Faktor ketidak percayaan muzaki pada pengelolaan dana zakat pada organisasi pengelola zakat baik itu Badan Amil Zakat (BAZ) maupun Lembaga Amil Zakat (LAZ) di Indonesia dikarenakan kurangnya transparansi pada Laporan Keuangan, Akuntabilitas dari pihak BAZ dan LAZ serta tidak mendapatkan manfaat 
yang lebih besar apabila dana zakat tersebut di salurkan melalui BAZ dan LAZ dibandingkan dengan penyaluran secara langsung.

Badan atau lembaga yang mengelola zakat, infaq, dan shadaqoh di Indonesia terdiri dari dua kelompok institusi, yaitu Badan Amil Zakat (BAZ) dan Lembaga Amil Zakat (LAZ) sesuai dengan Undang Undang No. 38 tahun 1999 tentang Pengelola Zakat Bab III pasal 6 dan pasal 7. BAZ dan LAZ ini merupakan salah satu dari delapan golongan asnaf yang berhak menerima zakat yaitu pada golongan AlAmilin. Menurut Prof Dr. Sjechul Hadi $(2005,290)$ bahwa biaya pengelolaan zakat secara keseluruhan tidak boleh lebih dari seperdelapan hasil pengumpulan zakat. Sehingga peran para amil zakat selaku pengemban amanah pengelolaan dana-dana zakat sangat mempengaruhi keputusan para muzaki untuk menyalurkan zakatnya kepada BAZ dan LAZ, jika amil zakat menjalankan amanah dengan baik maka tujuh Asnaf Mustahik lainnya Insya Allah akan terdistribusi dengan baik, tetapi sebaliknya jika amil zakatnya tidak menjalankan amanah dengan baik maka belum tentu tujuh Asnaf Mustahik yang lain akan mendapatkan dana zakat sesuai dengan proporsinya. Sehingga bagaimana BAZ dan LAZ itu dapat mengumpulkan dan menyalurkan dana zakat, infaq dan shodaqoh secara tepat dan amanah merupakan faktor penentu keputusan bagi muzaki untuk meyalurkan dana pada BAZ dan LAZ tersebut.

Tugas utama BAZ dan LAZ adalah untuk memungut dan mengumpulkan zakat, infaq dan shadaqoh dari masyarakat, kemudian menyimpannya di Baitull Mall. Setelah itu adalah menyalurkannya pada masyarakat sesuai dengan ketentuan syara'. Dalam pengumpulan, penyimpanan dan penyaluran zakat, infaq, dan shadaqoh tersebut pada masyarakat perlu adanya proses pencatatan transaksi keuangan hingga menghasilkan Laporan Keuangan yang transparan dan dapat dipertanggungjelaskan (accountability) yang memadai serta dapat dipertanggungjawabkan pada stakeholders.

Adanya pencatatan untuk setiap transaksi yang dilakukan dalam bermuamalah tersirat dalam dalam Al Quran Surat Al-Baqarah ayat 282 yang artinya adalah: "Hai orang-orang yang beriman, apabila kamu bermu'amalah tidak secara tunai untuk waktu yang ditentukan, hendaklah kamu menuliskannya. dan hendaklah seorang penulis di antara kamu menuliskannya dengan benar. dan janganlah penulis enggan menuliskannya sebagaimana Allah mengajarkannya, meka hendaklah ia menulis, dan hendaklah orang yang berhutang itu mengimlakkan (apa yang akan ditulis itu), dan hendaklah ia bertakwa kepada Allah Tuhannya, dan janganlah ia mengurangi sedikitpun daripada hutangnya. jika yang berhutang itu orang yang lemah akalnya atau lemah (keadaannya) atau Dia sendiri tidak mampu mengimlakkan, Maka hendaklah walinya mengimlakkan dengan jujur. dan persaksikanlah dengan dua orang saksi dari orang-orang lelaki (di antaramu). Jika tak ada dua oang lelaki, maka (boleh) seorang lelaki dan dua orang perempuan dari saksi-saksi yang kamu ridhai, supaya jika seorang lupa maka yang seorang mengingatkannya. janganlah saksi-saksi itu enggan (memberi keterangan) apabila mereka dipanggil; dan janganlah kamu jemu menulis hutang itu, baik kecil maupun besar sampai batas waktu membayarnya. yang demikian itu, lebih adil di sisi Allah dan lebih menguatkan 
persaksian dan lebih dekat kepada tidak (menimbulkan) keraguanmu. (Tulislah mu'amalahmu itu), kecuali jika mu'amalah itu perdagangan tunai yang kamu jalankan di antara kamu, Maka tidak ada dosa bagi kamu, (jika) kamu tidak menulisnya. dan persaksikanlah apabila kamu berjual beli; dan janganlah penulis dan saksi saling sulit menyulitkan. jika kamu lakukan (yang demikian), Maka Sesungguhnya hal itu adalah suatu kefasikan pada dirimu. dan bertakwalah kepada Allah; Allah Mengajarmu; dan Allah Maha mengetahui segala sesuatu.

Dari Al Qur'an Surat Al Baqarah ayat 282 tersebut menjelaskan bahwa setiap bermuamalah termasuk dalam penerimaan, penyimpanan dan penyaluran dana zakat, infaq dan shadaqoh dicatat dan dilaporkan kepada para stakeholders sehingga tidak akan ada lagi keraguan atau kekhawatiran dalam pengelolaan dana zakat yang dilakukan BAZ dan LAZ sehingga tercipta transparansi dalam pengelolaan dana zakat tersebut.

Sesuai dengan undang-undang No. 38 tahun 1999 tentang Pengelola Zakat, melahirkan paradigma baru dalam pengelolaan zakat yaitu perlu adanya pengikutsertaan masyarakat luar dan badan independen untuk turut serta mengawasi kegiatan pengelolaan secara langung. Dengan adanya badan independen atau auditor yang melakukan pemeriksaan dan pengawasan dalam laporan keuangan BAZ dan LAZ maka akan tercipta akuntabilitas dalam Laporan Keuangan atau laporan keuangan yang dilaporkan oleh BAZ dan LAZ dapat dipertanggungjawabkan dan dipertanggungjelaskan kepada pihak stakeholders.

Transparansi Laporan Keuangan dapat dianalogikan sebagai suatu sifat dan sikap organisasi pengelola zakat yaitu Tabligh, sesuai dengan Firman Allah SWT dalam QS Al Maidah ayat 67 "Hai Rasul sampaikanlah apa yang diturunkan kepadamu dari Tuhanmu dan jika tidak kamu kerjakan (apa yang diperintahkan itu, berarti) kamu tidak menyampaikan amanat-Nya". Dalam ayat tersebut tersirat bahwa Organisasi Pengelola Zakat harus memegang teguh aturan Allah, selalu menyampaikan segala sesuatu secara benar dan transparan, menjunjung tinggi kejujuran, melakukan pekerjaan dengan penuh dedikasi dan loyalitas yang tinggi.

Akuntabilitas Laporan Keuangan dapat dianalogikan sebagai suatu sifat dan sikap organisasi pengelola zakat yaitu Amanah, sesuai dengan Firman Allah SWT dalam QS An Nisa' ayat 58, "Sesungguhnya Allah menyuruh kamu menyampaikan amanat kepada yang berhak menerimanya." Dalam ayat tersebut tersirat bahwa Organisasi Pengelola Zakat harus dapat dipercaya dalam melakukan pengumpulan, penyimpanan dan pendistribusian dana ZIS kepada mereka yang berhak.

Penelitian ini bertujuan untuk mengetahui pengaruh tabligh dan amanah terhadap keputusan muzakki dalam penyerahan zakat, infaq, dan shadaqoh pada LAZ di Surabaya.

\section{KAJIAN PUSTAKA Laporan Keuangan}

Akuntansi merupakan suatu proses pencatatan transaksi keuangan suatu unit ekonomi sampai menjadi laporan keuangan. Laporan keuangan memberikan 
informasi dan memberikan tanggung jawab pada stakeholders atau para pemakai informasi untuk dijadikan dasar dari pengambilan keputusan. Untuk tujuan yang mulia tersebut dibutuhkan tata kelola suatu unit ekononi termasuk didalamnya BAZ dan LAZ di Surabaya secara profesional agar keputusan yang diambil stakeholders manjadi positif. Beberapa teori yang melandasi pengelolaan BAZ dan LAZ di Surabaya yang transparan dan akuntable yang berguna sebagai dasar pengambilan keputusan khususnya muzaki meliputi: Shariah Enterprise Theory, Agency Theory, dan Good Corporate Governance. Referensi mengenai transparansi laporan keuangan, akuntabilitas, dan manfaat terhadap pengambilan keputusan yang disajikan.

1. Shari'ah Enterprise Theory: dalam teori ini tanggung jawab terhadap stakeholders menjadi tujuan utama yang harus dipenuhi selain pertanggung jawaban kepada Allah.

2. Agency Theory: dalam teori ini dapat dijelaskan bahwa agen dapat dipercaya untuk melakasanakan tugas dan tanggung jawabnya dalam memaksimumkan kemakmuran. Namun karena ketimpangan informasi yang dimiliki agen dan pemilik membuat agen semena-mena mengunakan informasi tersebut untuk kepentinganya sendiri.

3. Good Corporate Governance: ada dua paradigma corporate governance, yaitu share holding dan stakeholding. Corporate governance menurut paradigma shareholding mempunyai tujuan hanya untuk memaksimumkan kemakmuran pemegang saham, sedangkan menurut paradigma stakeholding mempunyai tujuan untuk mengakomodir semua kepentingan stakeholders.

\section{Prinsip Tabligh (Transparansi).}

Prinsip transparansi adalah prinsip yang menjamin akses atau kebebasan bagi setiap orang untuk memperoleh informasi tentang penyelenggaraan organisasi, yakni informasi tentang kebijakan, proses pembuatan dan pelaksanaan, serta hasilhasil yang diperoleh.

Transparansi adanya kebijakan terbuka bagi pengawasan, informasi untuk para pengguna laporan keuangan. Informasi yang dibutuhkan adalah informasi mengenai semua aspek kebijakan organisasi yang dapat diakses publik, dengan keterbukaan informasi tersebut diharapkan akan menghasilkan persaingan yang sehat, kepercayaan stakeholders dan pengelolaan terhadap dana zakat, infaq dan shadaqoh sehingga dari informasi tersebut dapat dimanfaatkan sebagai pengambilan keputusan bagi para stakeholder. Transparansi harus seimbang dengan kebutuhan akan kerahasiaan lembaga maupun informasi-informasi yang mempengaruhi hak privasi individu. Karena organisasi menghasilkan data jumlah yang besar, maka dibutuhkan petugas informasi yang profesional, bukan untuk membuat dalih atas keputusan organisasi, tetapi untuk menyebarluaskan keputusan-keputusan yang penting kepada masyarakat.

KNKCG (Komite Nasional Kebijakan Corporate Governance) 2001, untuk menjaga obyektivitas dalam menjalankan bisnis, perusahaan harus menyediakan 
informasi yang material dan relevan dengan cara yang mudah diakses dan dipahami oleh pemangku kepentingan. Perusahaan harus mengambil inisiatif untuk mengungkapkan tidak hanya masalah yang disyaratkan oleh peraturan perundangundangan, tetapi juga hal yang penting untuk pengambilan keputusan oleh pemegang saham, kreditur dan pemangku kepentingan lainnya. Beberapa praktek yang dikembangkan dalam rangka transparansi diantaranya perusahaan diwajibkan untuk mengungkapkan transaksi-transaksi penting yang terkait dengan perusahaan, risikorisiko yang dihadapi dan rencana/kebijakan perusahaan (corporate action) yang akan dijalankan. Selain itu, perusahaan perlu untuk menyampaikan kepada seluruh pihak mengenai struktur kepemilikan perusahaan serta perubahan-perubahan yang terjadi. Transparansi diperlukan akibat adanya informasi yang tidak simentri (asymmetric information). Transparancy untuk menjaga obyektivitas dalam menjalankan bisnis, perusahaan harus menyediakan informasi yang material dan relevan dengan cara yang mudah diakses dan dipahami oleh pemangku kepentingan. Perusahaan harus mengambil inisiatif untuk mengungkapkan tidak hanya masalah yang disyaratkan oleh peraturan perundang-undangan, tetapi juga hal yang penting untuk pengambilan keputusan oleh pemegang saham, kreditur dan pemangku kepentingan lainnya. Transparansi adalah keterbukaan dalam melaksanakan proses pengambilan keputusan dan dalam mengemukakan informasi materiil dan relevan mengenai perusahaan. Transparansi berhubungan kualitas informasi disampaikan perusahaan. Kepercayaan investor sangat tergantung dengan kualitas informasi yang disampaikan perusahaan. Perusahaan dituntut untuk menyediakan informasi yang jelas, akurat, tepat waktu dan dapat dibandingkan dengan indikator-indikator yang sama. Penyampaian informasi kepada publik secara terbuka, benar, kredibel, dan tepat waktu akan memudahkankan untuk menilai kinerja dan resiko yang dihadapi perusahaan.

Beberapa praktek yang dikembangkan dalam rangka transparansi diantaranya perusahaan diwajibkan untuk mengungkapkan transaksi-transaksi penting yang terkait dengan perusahaan, risiko-risiko yang dihadapi dan rencana/ kebijakan perusahaan (corporate action) yang akan dijalankan. Selain itu, perusahaan perlu menyampaikan kepada seluruh pihak mengenai struktur kepemilikan perusahaan serta perubahan-perubahan yang terjadi. Transparansi diperlukan akibat adanya informasi yang tidak simentri (asymmetric information). Transparancy merupakan suatu bentuk pengungkapan (disclosure) setiap kebijakan atau aturan yang diterapkan perusahaan, sebab kepercayaan investor dan efisiensi pasar sangat tergantung dari pengungkapan kinerja perusahaan secara adil, akurat, dan tepat waktu. Prinsip keterbukaan atau transparansi, misalnya, organisasi harus memberikan informasi secara tepat waktu, memadai, jelas, akurat, dan dapat dibandingkan. Informasi tersebut juga harus mudah diakses stakeholders sesuai dengan haknya. 


\section{Prinsip Amanah (Akuntabilitas)}

"...orang yang dipercayai wajib memenuhi amanahnya, dan bertaqwalah kepada Allah Tuhannya. Jangan kamu sekali-kali menyembunyikan kesaksian. Barangsiapa yang menyembunyikannya, akan tercoreng dosa di hatinya, dan Allah maha mengetahui akan segala yang kamu lakukan." Al Baqarah 283.

Prinsip Akuntabilitas atau pertanggung jelasan dalam literatur dan pandangan barat terbentuk karena perlunya transparansi yang berawal dari adanya permasalahan tentang ketidakseimbangan informasi atau bisa disebut sebagai informasi asimetri (asimetric information). Informasi yang dibutuhkan oleh stakeholders biasanya tidak didapatkan sepenuhnya dari Laporan Keuangan. Selain itu akuntabilitas juga merupakan cerminan bahwa suatu perusahaan atau organisasi itu memiliki tata kelola yang baik (Good Coorporate Governance), bentuk akuntabilitas ini diwujudkan dalam bentuk pengungkapan (self disclosures) sebagai mekanisme yang memfasilitasi berbagai informasi mengenai sumber ekonomik yang dipercayakan oleh pemilik (principal) kepada manajemen (agent). Demikian halnya berlaku bagi organisasi nirlaba yaitu BAZ dan LAZ di Surabaya yang harus mengungkapkan seluruh transaksi baik itu penerimaan dan penyimpanan serta penyaluran zakat, infak dan shadaqoh dari muzaki karena muzaki telah mempercayakan dan mengamanahkan melalui BAZ dan LAZ tersebut untuk dikelola dan didistribusikan kepada pihakpihak yang memang berhak menerima.

Konsep pertanggungjelasan, dalam perspektif barat (konvensional), dimaknai sebagai tanggungjawab seseorang terhadap apa yang dipercayakan kepadanya untuk kemudian menyediakan informasi mengenai pertanggungjawabannya kepada mereka yang berhak terhadap informasi tersebut (Gray, 2001, p.11). Isu atau pertanyaan utama yang muncul dari definisi tersebut adalah siapa saja yang berhak atas informasi bisnis yang dimaksud dan sejauh mana informasi yang wajib disediakan. Jawaban atas pertanyaan ini tergantung dengan teori entitas mana yang dianut perusahaan. Berikut teori entitas yang relevan dibahas.

Konsep entitas usaha bisnis (bussiness entity theory) menegaskan bahwa perusahaan merupakan entitas yang berdiri sendiri dan bertindak atas namanya sendiri sehingga perusahaanlah yang menjadi fokus dan subjek pelaporan. Fungsi pengelolaan dan pemilikan terpisah sehingga hubungan perusahaan dengan pemegang ekuitas (equity holders), yaitu pemegang saham dan kreditor dipandang sebagai hubungan bisnis. Hubungan bisnis ini menghendaki agar manajemen bertanggungjelas kepada para pemegang ekuitas melalui penyajian laporan keuangan kesatuan usaha. Laporan keuangan ini lebih ditujukan untuk memenuhi persyaratan hukum dan menjaga hubungan baik, bukan untuk memenuhi pertanggungjelasan keuangan dan kepengurusan (financial and stewardship accountability) (Suwardjono, 2008).

Dalam konsep entitas usaha bersama (enterprise theory), yang menjadi pusat perhatian akuntansi adalah kegiatan usaha bersama yang melibatkan berbagai pihak sebagai bagian dari kegiatan ekonomik yang dilakukan. Dalam hal ini, perusahaan (terutama perusahaan besar) lebih cenderung sebagai institusi sosial daripada institusi 
bisnis, karena luas dan kompleksnya lingkup pertanggungjawaban sosial. Semua partisipan dalam usaha bersama ikut menanggung segala aspek kegiatan bisnis yang dijalankan. Partisipan tersebut terdiri dari manager, karyawan, pemegang saham, kreditor, pelanggan, pemerintah, dan masyarakat. Laporan nilai-tambahan (value added statement) merupakan laporan laba dari upaya bersama (cooperative effort) para stakeholder sebagai pengganti laporan laba rugi dalam teori entitas.

Teori entitas usaha yang digunakan (termasuk yang tidak dibahas seperti investor theory, proprietary theory, residual proprietary theory, commander theory, dan fund theory), subjek pertanggungjelasan entitas belum mencakup pertanggungjelasan entitas kepada Tuhan dan lingkungan. Inilah yang kemudian menjadi ciri utama perbedaan konsep pertanggungjelasan dan pertanggungjawaban antara akuntansi konvensional dengan akuntansi syariah.

Nilai, tata cara dan praktek hidup yang diatur islam merupakan sebuah dimensi universal yang mencakup keseluruhan aspek hidup manusia, di dunia maupun di akhirat. Nilai dasar ini diletakkan pada tiga pijakan utama, yaitu tauhid (keesaan), khilafah (perwakilan), dan keadilan (Chapra, 2000). Akuntansi sebagai bagian dari sisi kehidupan manusia tidak terlepas dari ketiga sumber nilai dasar tadi. Konsep tauhid adalah fondasi keimanan dalam Islam, yang kemudian mempengaruhi seluruh aspek kehidupan seorang muslim. Tauhid menyadarkan kita bahwa semua yang ada di jagat raya ini hakikatnya adalah milik Tuhan, bukan milik manusia, manusia harus bertanggungjawab terhadap apa yang telah diamanahkan kepadanya. Manusia juga dipercaya untuk memanfaatkan alam dalam rangka menyebarkan rahmat seluas-luasnya pada seluruh makhluk di bumi ini. Tugas kekhalifahan yang diemban hanya bersifat sementara, tidak sampai pada tingkat wewenang yang mutlak, dengan kata lain, bentuk kekhalifahan manusia harus diposisikan pada ketundukan terhadap syariah-Nya. Konsep keadilan juga harus ditempatkan pada posisi yang benar, yaitu keadilan yang seadil-adilnya adalah keadilan Tuhan, karena Dialah yang paling mengerti permasalahan ciptaannya. Keadilan versi manusia tidak selalu dapat diterima dalam tempat dan waktu tertentu, juga pasti selalu berubah. Islam dan syariahnya adalah agama yang relevan dimanapun, sampai kapanpun (all times, all places). Keadilan holistik akan dicapai bila manusia mengikuti standar ketentuan Tuhan.

Konsekuensi dari ketiga pijakan utama tersebut adalah kewajiban untuk mempertanggungjawabkan tugas dan usaha dalam mencapai tujuan yang telah ditetapkan, sebagai wakil dari Tuhan, dan dengan mengingat hakikat siapa pemilik semua yang ada di alam. Pertanggungjawaban manusia akan ditujukan kepada Allah, sesama manusia dan alam. Ketiganya tidak terpisah namun ketiganya harus dipandang secara utuh dalam sebuah ikatan pertanggungjawaban kepada Allah. Pertanggungjawaban kepada sesama manusia adalah turunan dari filosofi utama pertanggungjawaban kepada Allah. Begitu pula dengan tanggungjawab manusia terhadap sumber daya alam yang telah diciptakan untuk dikelola manusia. 
Bentuk pertanggungjawaban kepada Sang Pemilik Hakiki ini (tidak hanya kepada stakeholder) terwujudkan dalam rerangka konsep pelaporan keuangan yang berbasis pada aturan-Nya (syariah), sebagaimana dikatakan oleh Adnan (1999):

"Pada tataran ideal sesuai dengan peran manusia dimuka bumi dan hahekat pemilik segalanya (lihat Qs 2:30, 6:16, 3:109, 5:17) maka tujuan ideal adalah pertanggungjawaban muamalah kepada Sang Pemilik Hakiki, Allah SWT. Namun karena Tuhan Maha Mengetahui, tujuan ini bisa ditransformasikan dalam bentuk pengamalan apa yang sudah menjadi sunnah dan syariah-Nya."

Penyusunan teori dan standar pelaporan akuntansi syariah berfilosofi pada makna pertanggungjelasan ini. Standar Akuntansi Syariah yang sudah ada sekarang memang belum sepenuhnya memenuhi konsep pertanggungjelasan seperti yang telah disebutkan, apalagi praktik bisnisnya. Masih dibutuhkan semangat dan pemikiranpemikiran dari para cendikiawan muslim guna perbaikan dan pengembangan akuntansi syariah, sebuah bentuk pertanggungjawaban horisontal-vertikal sarat nilai.

KNKCG (Komite Nasional Kebijakan Corporate Governance) 2001, Perusahaan harus dapat mempertanggungjawabkan kinerja secara transparan dan wajar. Untuk itu perusahaan harus dikelola secara benar, terukur dan sesuai dengan kepentingan perusahaan dengan tetap memperhitungkan kepentingan pemegang saham dan pemangku kepentingan lain. Akuntabilitas merupakan prasyarat yang diperlukan untuk mencapai kinerja yang berkesinambungan. Accountability didasarkan pada sistem internal checks and balances yang mencakup praktik audit yang sehat dan dicapai melalui pengawasan yang efektif yang didasarkan pada keseimbangan kewenangan antara pemegang saham, komisaris dan eksekutif.

Pemegang saham melakukan investasi ke perusahaan dan sebagai imbal hasilnya menerima deviden dan capital gains. Kreditur memijamkan uang dan memperoleh pembayaran bunga. Karyawan menyumbangkan kemampuan dan pengetahuan mereka untuk memperoleh upah, gaji, bomus, dan peluang pengembangan professional. Rekanan mendapatkan pembayaran karena menyediakan bahan baku, sedangkan distributor dan pengecer terlibat dalam transaksi dengan perusahaan karena membantu distribusi produk dari pabrik ke outlet penjualan sampai pelanggan. Perusahaan memerlukan pelanggan yang tersedia untuk membeli produk atau jasa mereka. Hal-hal tersebut merupakan interaksi pasar fundamental yang dipunyai oleh setiap perusahaan dengan masyarakat.berarti perusahaan harus menetapkan tanggung jawab yang jelas dari setiap komponen organisasi selaras dengan visi, misi, sasaran usaha, dan strategi perusahaan. Setiap komponen organisasi mempunyai kompetensi sesuai dengan tanggung jawab masing-masing.

Akuntabilitas berhubungan dengan adanya sistem yang mengendalikan hubungan antar organ-organ yang ada di perusahaan dan diperlukan sebagai salah satu solusi mengatasi agency problem yang timbul antara pemegang saham dan direksi serta pengendaliannya oleh komisaris. Akuntabilitas dapat diterapkan dengan mendorong seluruh organ perusahaan menyadari tanggung jawab, wewenang dan hak kewajibannya. Accountability didasarkan pada sistem internal checks and balances 
yang mencakup praktik audit yang sehat dan dicapai melalui pengawasan yang efektif yang didasarkan pada keseimbangan kewenangan antara pemegang saham, komisaris dan eksekutif.

\section{Penelitian Sebelumnya}

Hasil penelitian tentang pengaruh transparansi laporan keuangan terhadap pengambilan keputusan para pemakai informasi laporan keuangan diantaranya adalah Irvan Abu Baker dan Chaider, (2006) pandangan kaum muslim terhadap transparansi informasi dapat dilihat sebagai berikut "Kepercayaan para donor terhadap organisasi keagamaan yang menyalurkan dana dengan transparan, penolakan terhadap pencarian dana dijalan-jalan raya karena akuntabilitas yang rendah, keinginan untuk mengaudit organisasi-organisasi”. Levesque dan McDouglas (1998) menunjukkan bahwa kemampuan organisasi dalam memberikan manfaat sosial pada masyarakat maka akan dapat diterima dimana organisasi itu berada dan masyarakat luas dapat memberikan dukungan positif terhadap kelancaran organisasi.

\section{Landasan Kewajiban Zakat}

Undang-Undang (UU) No. 38. tahun 1999 tentang ketentuan pengelolaan zakat bab III pasal 6 dan 7 menyatakan bahwa lembaga pengelola zakat di Indonesia terdiri atas dua kelompok institusi, yaitu Badan Amil Zakat (BAZ) dan Lembaga Amil Zakat (LAZ). BAZ dibentuk pemerintah, sedangkan LAZ dibentuk oleh masyarakat. Zakat adalah rukun Islam ketiga yang diwajibkan di Madinah pada bulan Syawal tahun kedua Hijriyah setelah diwajibkannya puasa Ramadhan dan zakat Fitrah. Ayat-ayat zakat, shodaqah dan infaq yang turun di Makkah baru berupa anjuran dan penyampaiannya menggunakan metodologi pujian bagi yang melaksanakannya dan cacian atau teguran bagi yang meninggalkannya.

Landasan kewajiban zakat disebutkan dalam Al Qur'an, Sunnah dan Ijma Ulama.

1. Al Qur'an

a) Surat Al-Baqaraah ayat 43. Artinya: "Dirikanlah shalat dan tunaikanlah zakat dan ruku'lah bersama dengan orang-orang yang ruku' ".

b) Surat At-Taubah ayat 103: Artinya: "Ambilah zakat dari sebagian harta mereka, dengan zakat itu kamu membersihkan dan mensucikan mereka dan do'akanlah mereka karena sesungguhnya do'amu dapat memberikan ketenangan bagi mereka. Dan Allah Maha Mendengar lagi Maha Mengetahui".

c) Surat Al An'aam ayat 141: Artinya: "Makanlah buahnya jika telah berbuah dan tunaikan haknya (kewajibannya) dihari memetik hasilnya (dengan dikeluarkan zakatnya)".

2. Sunnah

a) Rasulullah saw bersabda yang diriwayatkan Bukhari dan Muslim dari Abdullah bin Umar: Artinya: "Islam dibangun atas lima rukun: Syahadat tiada Tuhan kecuali Allah dan Muhammad SAW utusan Allah, menegakkan shalat, membayar zakat, menunaikan haji dan puasa Ramadhan". 
b) Hadist diriwayatkan oleh Ath-Thabrani dari Ali ra: Artinya:

"Sesungguhnya Allah mewajibkan (zakat) atas orang-orang kaya dari umat Islam pada harta mereka dengan batas sesuai kecukupan fuqoro diantara mereka. Orang-orang fakir tidak akan kekurangan pada saat mereka lapar atau tidak berbaju kecuali karena ulah orang-orang kaya diantar mereka. Ingatlah bahwa Allah akan menghisab mereka dengan keras dan mengadzab mereka dengan pedih".

3. Ijma

Ulama baik salaf (klasik) maupun khalaf (kontemporer) telah sepakat akan kewajiban zakat dan bagi yang mengingkarinya berarti telah kafir dari Islam.

\section{Kedudukan Hukum Zakat}

Dalam akhir abad kedua puluh ini, bersamaan dengan kebangkitan kembali umat Islam diberbagai sektor kehidupan, ajaran zakat juga menjadi salah satu sektor yang mulai digali dari berbagai dimensinya. Meningkatnya kesejahteraan umat Islam memberikan harapan baru dalam mengaktualisasikan zakat. Apalagi kebangkitan ekonomi di dunia barat khususnya yang didasari pemikiran kapitalistik telah menimbulkan berbagai masalah dalam kehidupan ini seperti kesenjangan dalam kehidupan sosial ekonomi.

Gerakan kesadaran membayar perlu zakat diiringi oleh dukungan dari masyarakat dan juga pemerintah. Di Indonesia pengelolaan zakat diatur berdasarkan UU No. 38 tahun 1999 tentang pengelolaan zakat dengan Keputusan mentri Agama (KMA) No. 581 tahun 1999 tentang Pelaksanaan UU No. 38 tahun 1999 dan keputusan Direktur Jendral Bimbingan Masyarakat Islam dan Urusan Haji No. D/291 tahun 2000 tentang Pedoman Teknis Pengelolaan Zakat.

Dalam Bab II pasal 5 UU tersebut dikemukakan bahwa pengelolaan zakat bertujuan :

1. Meningkatkan pelayanan bagi masyarakat dalam menunaikan zakat sesuai tuntunan agama.

2. Meningkatkan fungsi dan peranan pranata keagamaan dalam upaya mewujudkan kesejahteraan masyarakat dan keadilan sosial.

3. Meningkatkan hasil guna dan daya guna zakat.

\section{Muzakki dan Mustahik Zakat}

Muzakki atau pembayar zakat adalah orang yang hartanya dikenakan kewajiban zakat. Seorang pembayar zakat disyaratkan harus seorang muslim dan tidak disyaratkan baligh atau berakal menurut pendapat ulama jumhur. Sedangkan Mustahik adalah kelompok orang yang berhak menerima zakat. Sesuai dengan firman Allah SWT :

"Sesungguhnya zakat-zakat itu hanya disalurkan untuk orang-orang fakir, orang-orang miskin, pengurus-pengurus zakat, para muallaf, memerdekakan budak. Orang-orang berutang, fi sabilillah dan orang-orang yang sedang dalam perjalanan, 
sebagai sesuatu ketetapan yang diwajibkan Allah sesungguhnya Allah Maha Mengetahui Lagi Maha Bijaksana "( Q.S At- Taubah: 60)

1. Fakir, yaitu sekelompok masyarakat yang tidak dapat memenuhi kebutuhan pokoknya (primer). Sedangkan ulama berpendapat fakir adalah orang yang tidak memiliki nisab zakat.

2. Miskin, yaitu kelompok masyarakat yang memiliki kurang biaya yang diperlukan untuk memenuhi kebutuhan sendiri, keluarga serta orang lain yang berada dalam tanggungannya. Ada ulama yang berpendapat orang miskin adalah orang yang tidak mempunyai harta sama sekali.

3. Amil (Pengurus Zakat), adalah pihak yang diangkat pemerintah atau masyarakat untuk menangani urusan pemungutan zakat dari sumbernya dan menyalurkannya kepada yang membutuhkan.

4. Muallaf, yaitu kelompok masyarakat dari orang-orang yang baru memeluk Islam yang diberikan Zakat untuk membujuk hati mereka untuk tetap dalam Islam atau memantapkan keimanan mereka.

5. Membebaskan orang dari perbudakan, hamba sahaya yang diberikan zakat unutk memerdekakan diri mereka dari perbudakan.

6. Yang dililit utang (Ghamirin), mereka adalah kelompok masyarakat yang dibebani utang pribadi dan tidak memiliki harta untuk melunasinya atau orang yang menanggung pembayaran diyat pembunuhan untuk memperbaiki hubungan kekeluargaan atau orang yang menanggung utang tertentu.

7. Kegiatan dijalan Allah (fisabilillah), jihad dijalan Allah SWT dan kegiatan sejenisnya dalam rangka dakwah.

8. Musafir, musafir yang jauh dari negerinya dan telah menutup semua sumber rezekinya.

\section{Manfaat Zakat Dalam Kehidupan Masyarakat Islam}

Beberapa manfaat dan hikmah zakat menurut Heri Sudarsono dalam bukunya

Bank dan Lembaga Keuangan Syariah (2003) dapat dikemukakan sebagai berikut:

1. Menghindari kesenjangan sosial antara aghniya dan dhu ‘afa.

2. Alat pembersih harta dan penjagaan dari ketamakan orang jahat.

3. Menjadi unsur penting dalam mewujudkan keseimbangan dalam distribusi harta (social distribution) dan keseimbangan tanggungjawab individu dalam masyarakat.

4. Menunjang terwujudnya sistem kemasyarakatan Islam yang terdiri atas prinsipprinsip : ummatan wahidan (umat yang satu), musawah (persamaan derajat), ukhwah islamiyah (persaudaraan islam) dan tafakul ijti ma (tanggung jawab bersama).

5. Dapat mensucikan diri (pribadi) dari kotoran dosa, memurnikan jiwa dan menumbuhkan akhlaq mulia dan mengikis sifat bakhil (kikir).

6. Zakat adalah ibadah maaliyah yang mempunyai dimensi dan fungsi sosial ekonomi atau pemerataan karunia Allah dan juga merupakan perwujudan solidaritas sosial, pernyataan rasa kemanusiaan dan keadilan, dan pengikat 
persatuan ummat dan bangsa sebagai pengikat bathin antara golongan kaya dengan yang miskin dan sebagai penimbun jurang pemisah antara golongan yang kuat dengan yang lemah.

\section{Konsep Akuntansi Zakat}

Kemunculan Lembaga Keuangan Islam khususnya Lembaga Pengelolaan Zakat sebagai organisasi yang relatif baru menimbulkan tantangan besar. Para pakar syariah Islam dan akuntansi harus mencari dasar bagi penerapan dan pengembangan standar akuntansi yang berbeda dengan standar akuntansi bank dan lembaga keuangan konvensional seperti telah dikenal selama ini.

Standar akuntansi tersebut menjadi kunci sukses Lembaga Pengelolaan Zakat dalam melayani masyarakat di sekitarnya sehingga, seperti lazim-nya, harus dapat menyajikan informasi yang cukup, dapat dipercaya, dan relevan bagi para penggunanya, namun tetap dalam konteks syariah Islam. Akuntabilitas organisasi pengelola zakat ditunjukkan dengan laporan keuangan serta audit terhadap laporan keuangan tersebut. Untuk bisa disahkan sebagai organisasi resmi, lembaga zakat harus menggunakan sistem pembukuan yang benar dan siap diaudit akuntan publik. Ini artinya standar akuntansi zakat mutlak diperlukan.

Sayangnya, sampai saat ini belum terdapat standar akuntansi zakat untuk lembaga pengelola zakat. Namun berdasarkan tesis yang dibuat oleh Anies said M. Basalamah, MBA, Ak., yang berjudul Akuntansi Zakat, Infaq dan Shadaqoh : Pembukuan dan Pelaporannya, dapat dijadikan acuan dalam membuat laporan keuangan zakat. Riset yang dilakukan oleh Anies Basalamah ini mengenai pengumpulan, pendistribusian dan pelaporan zakat dan shodaqoh di empat negara, yaitu Kanada, Indonesia, Pakistan dan Amerika Serikat.

Anies Basalamah mengklasifikasikan donasi yang dikumpulkan dalam Lembaga Amil Zakat menjadi tiga bentuk, yaitu:

1. Shodaqoh yang tidak dimaksudkan oleh pemberinya untuk tujuan tertentu. Shodaqoh jenis ini merupakan dana yang tidak terbatas (unrestricted funds). Artinya, dana ini dapat digunakan untuk siapa saja selain kedelapan asnaf, baik muslim maupun non muslim.

2. Shodaqoh yang dimaksudkan oleh pemberinya untuk diberikan dengan tujuan tertentu atau diberikan kepada penerima tertentu.

3. Zakat, yang dapat digolongkan sebagai dana yang terbatas penggunaannya (restricted funds) karena ia dibatasi oleh siapa atau dari sumber mana zakat ini berasal dan kepada siapa saja zakat ini disalurkan.

Selanjutnya, Anies Basalamah membagi sistem akuntansi dan pelaporan untuk LAZ menjadi dua bagian, yaitu untuk dana yang terbatas (restricted funds) yaitu zakat dan infaq, dan untuk dana yang tidak terbatas (unrestricted funds), yaitu dana shodaqoh. 


\section{Fungsi dan Peran Lembaga Amil Zakat (LAZ)}

Fungsi dan peran Lembaga Amil Zakat (LAZ) menurut Sjechul Hadi Permono $(2005,362)$ adalah:

1. Lembaga Amil Zakat menjamin terlaksananya Syariat Islam, karena pelaksanaan pengumpulan hingga pendistribusian ZIS harus selalu dilakukan pengawasan.

2. Pengumpulan ZIS melalui Lembaga Amil Zakat diharapkan dapat merata dalam pendistribusiannya.

3. Pengumpulan ZIS melalui Lembaga Amil Zakat lebih mulia, karena Muzakki tidak perlu bertatap muka langsung dengan pihak Mustahik sehingga dapat menjaga harkat dan martabat kedua belah pihak.

4. Zakat, Infaq dan Shodaqoh lebih terarah pada 8 asnaf dan tidak saja dapat disalurkan melalui individu tertentu tetapi juga dapat melalui Lembaga yang dikelola secara lebih produktif.

\section{METODE PENELITIAN}

\section{Jenis Penelitian}

Berdasarkan tujuan penelitian yang ingin dicapai, maka penelitian ini digolongkan kepada penelitian kausatif. Menurut Indriantoro (1999:27) penelitian kausatif adalah "Tipe penelitian dengan karakteristik masalah berupa hubungan sebab akibat antara dua variabel atau lebih". Penelitian ini akan melihat sejauh mana hubungan antara variabel-variabel yang berpengaruh terhadap transparansi informasi dan akuntabilitas serta pengaruhnya terhadap keputusan muzaki untuk mengeluarkan ZIS.

\section{Populasi dan Sampel}

Populasi menurut Indriantoro dan Supomo (1999:115) adalah, "Sekelompok orang, kejadian atau segala sesuatu yang memiliki karakteristik tertentu". Populasi dalam penelitian ini adalah seluruh muzaki LAZ di Surabaya yang berdiri minimal 5 tahun. Dalam penelitian ini populasi dibedakan atas populasi sasaran dan populasi terjangkau. Populasi sasaran didefinisikan sebagai totalitas group dari responden yang dijadikan sasaran penelitian, kemudian populasi terjangkau didefinisikan sebagai populasi yang ada pada saat penelitian dilaksanakan dan memungkinkan untuk dijadikan sebagai populasi.

Sampel adalah bagian dari jumlah dan karakteristik yang dimiliki oleh populasi tersebut (Sugiyono, 2004). Kriteria sampel pada penelitian ini adalah, sampel harus menjadi donatur dari LAZ lebih dari 1 tahun. Keseluruhan jumlah sampel yang diambil adalah sebanyak 50 orang sampel dari seluruh muzaki BAZ/ LAZ di Surabaya. 


\section{Metode Pengumpulan Data}

Dalam penelitian ini pengumpulan data yang dilakukan adalah:

a. Kuesioner

Merupakan pengumpulan data yang dilaksanakan dengan menyebarkan kuestioner secara langsung kepada responden (muzaki BAZ/LAZ di Surabaya) dengan tujuan untuk meningkatkan jumlah kuestioner yang dikembalikan oleh responden. Metode ini memerlukan adanya kontak antara peneliti dengan subyek (responden) penelitian untuk memperoleh data yang diperlukan. Pertanyaan dan jawaban responden dapat dikemukan secara tertulis melalui suatu kuestioner. Teknik ini memberikan tanggungjawab kepada responden untuk membaca dan menjawab pertanyaan. Kuestioner dapat didistribusikan dengan disampaikan secara langsung oleh peneliti kepada responden. Hal ini dilakukan agar response rate dari kuestioner tinggi dan peneliti dapat melakukan kontrol atas jawaban responden (Nur Indriantoro dan Bambang Supomo, 1999: 152)

b. Wawancara (Interview)

Yaitu teknik pengumpulan data yang dilakukan dengan cara tanya jawab dengan muzaki mengenai masalah yang dihadapi.

c. Dokumentasi

Metode ini digunakan untuk memperoleh data sekunder, yaitu data internal BAZ/LAZ di Surabaya, yaitu meliputi gambaran umum perusahaan, data muzaki, sitem, kebijakan organisasi dan lain-lainnya

\section{Sumber Data}

Penelitian ini mengunakan sumber data sebagai berikut:

a. Data Primer

Merupakan sumber data penelitian yang langsung diperoleh dari sumber asli atau tidak melalui perantara dan secara khusus dikumpulkan oleh peneliti untuk menjawab pertanyaan penelitian (Nur Indriantoro dan Bambang Supomo, 1999: 146). Data primer dalam penelitian ini adalah jawaban responden atas pernyataanpernyataan dari kuestioner yang disebarkan.

b. Data Sekunder

Data sekunder yaitu sumber data penelitian yang diperoleh peneliti secara tidak langsung melalui media perantara/diperoleh dan dicatat oleh pihak lain (Indriantoro, 1999:147). Teknik yang digunakan dalam pengumpulan data sekunder diperoleh dari studi kepustakaan yang relevan dengan penelitian, serta data berupa gambaran umum perusahaan yang didapat majalah-majalah atau melalui internet.

\section{Kerangka Konseptual}

Pada prinsipnya, penyusunan sebuah kerangka konseptual tidak harus didasarkan pada referensi hasil penelitian sebelumnya (empiris). Pada penelitian ilmu ekonomi Islam belum banyak dilakukan dan jangan sampai tercemar oleh landasan teori atau landasan empiris ilmu ekonomi konvensional. Agar pengembangannya 
lebih leluasa dan memberikan konstribusi signifikan bagi pengembangan ilmu ekonomi Islam.

Berdasarkan latar belakang, tujuan penelitian dan tinjauan kepustakaan yang telah dijelaskan pada bab sebelumnya maka dapat disusun kerangka konseptual sebagai berikut:

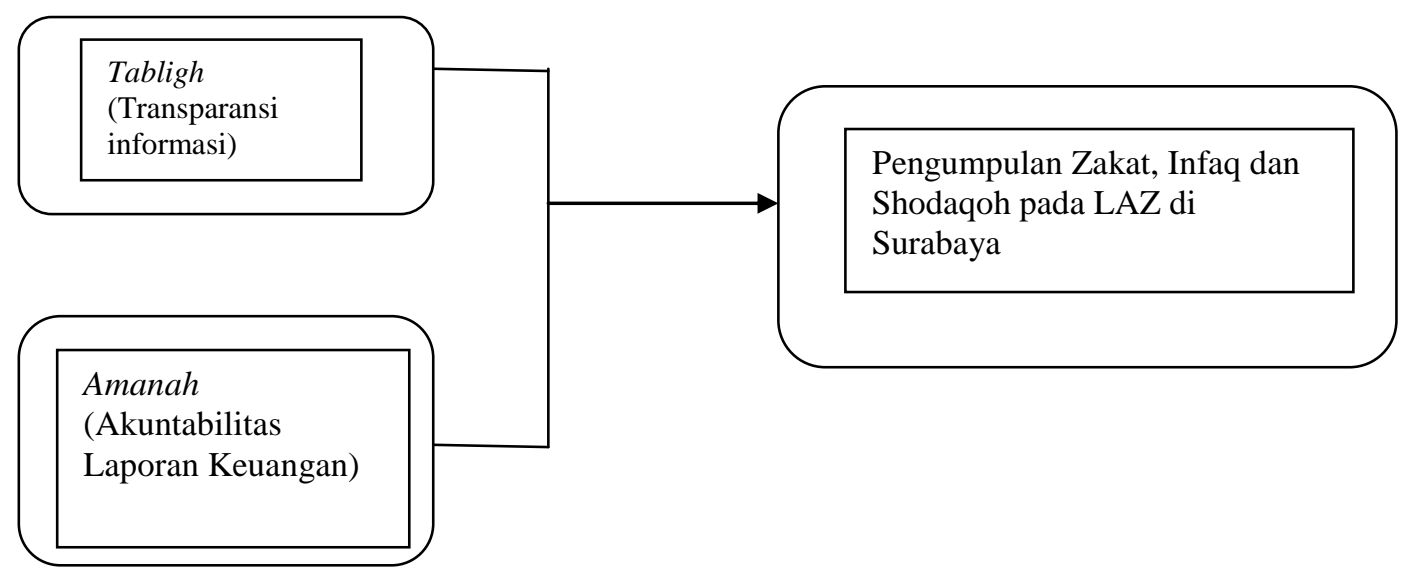

\section{Gambar 1. Kerangka Konseptual}

\section{Definisi Operasional Variabel}

1. Transparansi informasi BAZ/LAZ adalah prinsip yang menjamin akses atau kebebasan bagi setiap orang untuk memperoleh informasi tetang penyelenggaraan BAZ/LAZ, yakni informasi tentang kebijakan, proses pembuatan dan pelaksanaan, serta hasil-hasil yang dicapai.

2. Akuntabilitas merupakan pertanggung jawaban pihak BAZ/LAZ untuk mengelola BAZ/LAZ kepada seluruh stakeholders.

Variabel-variabel penelitian tersebut diukur berdasarkan indikator-indikator yang dimiliki masing-masing variabel dengan menggunakan skala sematik differensial, pada rentang angka 1 sampai dengan 10 dengan batasan kriteria sebagai berikut:

a. Tabligh (Transparansi informasi) LAZ

Angka 1: menunjukkan pengelola LAZ sangat tidak transparan sekali.

10: menunjukkan pengelola LAZ sangat transparan sekali.

b. Amanah (Akuntabilitas) LAZ

Angka 1: menunjukkan pengelola LAZ sangat tidak akuntable sekali.

10: menunjukkan pengelola LAZ sangat akuntable sekali.

c. Pengumpulan Zakat, Infaq dan Shodaqoh pada LAZ

Angka 1: menunjukkan Pengumpulan Zakat, Infaq dan Shodaqoh pada LAZ sangat tidak baik sekali.

Angka 10: menunjukkan Pengumpulan Zakat, Infaq dan Shodaqoh pada LAZ sangat baik sekali. 
Uji reliabilitas menunjukkan sejauh mana suatu hasil pengukur relatif konsisten walaupun diberikan kepada orang yang berbeda dengan pertanyaan yang sama. Uji reliabilitas dilakukan dengan menggunakan Cronbach aplikasi SPSS untuk mengetahui apakah pengukuran yang digunakan reliabel.

\section{Koefisien Korelasi}

Koefisien korelasi merupakan cara yang digunakan untuk melihat derajat hubungan antara variabel dependen.

Dimana :

1. bila $\mathrm{R}=0$ atau mendekati 0 maka hubungan antara variabel independen dengan variabel dependen sangat lemah atau tidak terdapat hubungan sama sekali.

2. Bila $\mathrm{R}=+1$ atau mendekati maka hubungan antara variabel independen dengan variabel dependen sangat kuat sekali dan dapat dikatakan bahwa hubungan yang terjadi adalah positif

3. Bila $\mathrm{R}=-1$ atau mendekati -1 maka hubungan antara variabel independen dan variabel dependen sangat kuat dan dapat dikatakan bahwa hubungan yang terjadi adalah negatif.

\section{Koefisien determinasi $\left(\mathbf{R}^{2}\right)$}

Koefisien determinasi merupakan cara yang digunakan untuk menjelaskan seberapa besar bariabel independet mempunyai kontribusi terhadap variabel dependen.

$\mathrm{R}^{2}$ berada antara 0 dan 1 yang berarti ;

1. bila $\mathrm{R}^{2}=1$ artinya kontribusi variabel independen terhadap variabel dependen adalah $100 \%$ dimana pendekatan model yang dgunakan adalah tepat.

2. bila $\mathrm{R}^{2}=0$ artinya tidak ada kontribusi dari variabel independen terhadap variabel dependen. Semakin tinggi $\mathrm{R}^{2}$ atau mendekati 1 maka makin besar pengaruh variabel independent terhadap variabel dependen.

Asumsi-asumsi yang digunakan apabila dalam menggunakan regresi antara lain adalah kolinieritas ganda (multikolinieritas) dan heteroskesdastisitas.

1. Dalam penelitian ini, kolinieritas ganda atau multikolieneritas diuji dengan menggunakan matriks korelasi antara masing-masing variabel bebas yang membandingkan dengan nilai kritisnya. Jika koefisien matriks korelasi antara variabel bebas lebih kecil dari nilai kritis, maka antara variabel bebas tersebut tidak terjadi kolienearitas berganda dan sebaliknya.

2. Uji Heterokesdastisitas, dilakukan dengan menggunakan korelasi rank Spearman, atau melakukan regresi antara nilai residual dengan nilai masing-masing variabel bebas. Jika terjadi hubungan yang signifikan berarti terjadi heteroskesdastisitas dan sebaliknya bebas dari asumsi heteroskesdastisitas jika koefisien korelasinya tidak signifikan. 
Sementara untuk menguji hipotesis penelitian, maka dilakukan pengujian dengan menggunakan uji $\mathrm{F}$ dan uji $\mathrm{t}$ dengan penjelasan sebagai berikut:

1. Uji F. Uji ini digunakan untuk menguji pengaruh variabel-variabel bebas terhadap variabel terikat secara bersama-sama. Bila $\mathrm{F}$ hitung memiliki tingkat signifikasi lebih rendah dari 0,05, maka dikatakan ada pengaruh signifikan.

2. Uji t. Uji ini digunakan menguji pengaruh variabel bebas secara parsial terhadap variabel terikat secara bersama-sama.

\section{HASIL DAN PEMBAHASAN}

Analisis Hasil Penelitian

Profil mengenai kondisi responden yaitu pembayar zakat (muzaki) LAZ di Surabaya dalam pnelitian yang meliputi jenis kelamin, pendidikan, dan posisinya sebagai muzaki pada LAZ dapat dilihat dalam tabel diatas. Selanjutnya untuk mengetahui atau mengenal karakteristik kondisi responden pada penelitian ini secara rinci dapat diuraikan Tabel 3.

Tabel 2. Profil Responden

\begin{tabular}{|c|c|c|c|c|}
\hline No & & angan & Frekuensi & $\%$ \\
\hline \multirow[t]{2}{*}{1} & Jenis Kelamin & Laki-laki & 43 & 61,4 \\
\hline & & Perempuan & 27 & 38,6 \\
\hline \multirow[t]{5}{*}{2} & Pendidikan & SMP & 1 & 1,4 \\
\hline & & SMA & 7 & 10,0 \\
\hline & & Diploma & 8 & 11,4 \\
\hline & & Sarjana & 31 & 44,3 \\
\hline & & $\mathrm{S} 2$ & 23 & 32,9 \\
\hline \multirow[t]{7}{*}{3} & LAZ & Dhompet Dhuafa & 6 & 8,6 \\
\hline & & LMI & 3 & 4,3 \\
\hline & & $\mathrm{BMH}$ & 3 & 4,3 \\
\hline & & PKPU & 5 & 7,1 \\
\hline & & Lagzis & 17 & 24,3 \\
\hline & & YDSF & 30 & 42,9 \\
\hline & & Lain-lain & 6 & 8,6 \\
\hline
\end{tabular}

Sumber: Data diolah dari kuesioner

Tabel 3. Hasil Analisis Deskriptif Jenis kelamin

\begin{tabular}{llllll}
\hline & & Frequency & \multicolumn{1}{c}{ Percent } & \multicolumn{1}{c}{$\begin{array}{c}\text { Valid } \\
\text { Percent }\end{array}$} & $\begin{array}{c}\text { Cumulative } \\
\text { Percent }\end{array}$ \\
\hline Valid & Laki-laki & 43 & 61,4 & 61,4 & 61,4 \\
& Perempuan & 27 & 38,6 & 38,6 & 100,0 \\
& Total & $\mathbf{7 0}$ & $\mathbf{1 0 0 , 0}$ & $\mathbf{1 0 0 , 0}$ & \\
\hline
\end{tabular}

Sumber data: Diolah dari kuesioner. 
Pada tabel 3 dapat dilihat bahwa dari 70 responden, 27 responden berjenis kelamin perempuan dan 43 responden berjenis kelamin laki-laki atau 61,4\% responden berjenis kelamin laki2 dan 38,6\% responden berjenis kelamin perempuan.

Dari tabel 4 dapat dilihat bahwa tingkat pendidikan responden dari total responden sejumlah 70 orang, 1.4\% merupakan muzakki dengan berpendidikan SMP atau sebesar 1 responden, 10\% responden merupakan muzzaki dengan berpendidikan SMA atau sebesar 7 responden, $11.4 \%$ responden merupakan muzzaki dengan berpendidikan Diploma atau sebesar 8 responden, $44.3 \%$ responden merupakan muzzaki dengan berpendidikan Sarjana atau sebesar 31 responden, 32.9\% responden merupakan muzzaki dengan berpendidikan S2 atau sebesar 23 responden. Dengan demikian dapat disimpulkan bahwa muzaki yang membayar zakat pada LAZ di Surabaya mempunyai tingkat pendidikan yang baik.

Tabel 4. Hasil Analisis DeskriptifPendidikan

\begin{tabular}{llllll}
\hline & & Frequency & Percent & Valid Percent & $\begin{array}{l}\text { Cumulative } \\
\text { Percent }\end{array}$ \\
\hline Valid & SMP & 1 & 1,4 & 1,4 & 1,4 \\
& SMA & 7 & 10,0 & 10,0 & 11,4 \\
& Diploma & 8 & 11,4 & 11,4 & 22,9 \\
& Sarjana & 31 & 44,3 & 44,3 & 67,1 \\
& S2 & 23 & 32,9 & 32,9 & 100,0 \\
& Total & $\mathbf{7 0}$ & $\mathbf{1 0 0 , 0}$ & $\mathbf{1 0 0 , 0}$ & \\
\hline
\end{tabular}

Sumber: Diolah dari kuesioner

Tabel 5. Hasil Analisis Deskriptif Lembaga Amil Zakat

\begin{tabular}{llllll}
\hline & & Frequency & Percent & Valid Percent & $\begin{array}{l}\text { Cumulative } \\
\text { Percent }\end{array}$ \\
\hline Valid & Dhompet Dhuafa & 6 & 8,6 & 8,6 & 8,6 \\
& LMI & 3 & 4,3 & 4,3 & 12,9 \\
& BMH & 3 & 4,3 & 4,3 & 17,1 \\
PKPU & 5 & 7,1 & 7,1 & 24,3 \\
Lagzis & 17 & 24,3 & 24,3 & 48,6 \\
& YDSF & 30 & 42,9 & 42,9 & 91,4 \\
& Lain-lain & 6 & 8,6 & 8,6 & 100,0 \\
Total & $\mathbf{7 0}$ & $\mathbf{1 0 0 , 0}$ & $\mathbf{1 0 0 , 0}$ & \\
\hline
\end{tabular}

Sumber: Diolah dari kuesioner 
Dari tabel 5 dapat dilihat bahwa jumlah muzaki pada LAZ dari total responden sejumlah 70 orang, 8.6\% merupakan muzakki dari dhompet dhuafa atau sebesar 6 responden, $4.3 \%$ responden merupakan muzzaki dari LMI atau sebesar 3 responden, $4.3 \%$ responden merupakan muzzaki dari BMH atau sebesar 3 responden, 7.1 \% responden merupakan muzzaki dari PKPU atau sebesar 5 responden, $24.3 \%$ responden merupakan muzzaki dari Lagzis atau sebesar 17 responden, $42.9 \%$ responden merupakan muzzaki dari YDSF atau sebesar 30 responden, dan $8.6 \%$ responden merupakan muzzaki diluar ke 5 lembaga besar LAZ di Indonesia atau sebesar 6 responden, sehingga responden terbesar merupakan muzzaki pada YDSF sebesar $42,9 \%$.

\section{Analisis Model dan Pengujian Hipotesis Analisis Regresi}

Hasil analisis deskriptif secara rinci untuk tiap indikator dari masing-masing variabel dapat dilihat pada Tabel 5 dan Tabel 6. Tabel-tabel berikut merupakan skor setiap indikator dari setiap variabel penelitian.

Tabel 6 menunjukkan bahwa responden penelitian secara umum beranggapan bahwa Lembaga Amil Zakat telah melakukan pengelolaan dana Zakat, Infaq dan Shodaqoh secara tabligh, dengan hasil analisis sebesar 8

Pada tabel 6 Tampak Indikator-indikator penelitian untuk menganalisis tabligh pada pengelolaan zakat infaq dan sodaqoh pada Lembaga Amil Zakat:

1. Lembaga Amil Zakat memiliki nilai transparansi dalam hal pengelolaan dana zakat, infaq dan shodaqoh dibawah nilai 10 (sangat transparan), atau dengan nilai rata-rata sebesar: 8

2. Informasi mengenai pengelolaan zakat, infaq dan shodaqoh dapat dengan mudah diakses oleh muzzaki memiliki nilai dibawah 10 (sangat mudah), atau dengan nilai rata-rata sebesar: 8

3. Nilai Publikasi dibawah 10 (sangat terpublikasi) atau dengan nilai rata-rata sebesar:8 Lembaga Amil Zakat melakukan publikasi di media massa mengenai kondisi Laporan Keuangannya.

4. Nilai Kemudahan Pengawasan dibawah 10 (sangat mudah) atau dengan nilai ratarata sebesar: 7 dimana Muzzaki kurang dapat melakukan pengawasan terhadap dana Zakat, Infaq dan Shodaqoh yang dikelola oleh Lembaga Amil Zakat.

5. Nilai Keterbukaan dibawah 10 (sangat terbuka) atau dengan nilai rata-rata sebesar: 7, dimana Lembaga Amil Zakat telah mencantumkan pihak-pihak yang menjadi donatur.

6. Nilai Keseimbangan dibawah 10 (sangat seimbang) atau dengan nilai rata-rata sebesar: 6, dimana Lembaga Amil Zakat belum memberikan informasi yang seimbang atau merata kepada masyarakat mengenai pengelolaan dana Zakat, Infaq dan Shodaqoh. 
7. Nilai Keseimbangan dibawah 10 (sangat seimbang) atau dengan nilai rata-rata sebesar: 7, dimana Lembaga Amil Zakat tidak memberikan informasi yang seimbang kepada manajemen dengan masyarakat luas.

Tabel 7. menunjukkan bahwa responden penelitian secara umum beranggapan bahwa Lembaga Amil Zakat telah melakukan pengelolaan dana Zakat, Infaq dan Shodaqoh secara amanah, dengan hasil analisis sebesar 8.

Pada tabel 7. Tampak Indikator-indikator penelitian untuk menganalisis amanah pada pengelolaan zakat infaq dan sodaqoh pada Lembaga Amil Zakat:

1. Lembaga Amil Zakat memiliki nilai amanah yang cukup tinggi meskipun dibawah nilai 10 (sangat transparan), atau dengan nilai rata-rata sebesar: 8, dengan demikian muzzaki menilai bahwa LAZ cukup amanah dan bertanggungjawab dalam menyajikan, melaporkan dan mengungkapkan aktifitas pengumpulan dan penyaluran zakat, infaq dan shodaqoh.

2. Nilai Keterstandaran Laporan Keuangan dibawah 10 (sesuai standar), atau dengan nilai rata-rata sebesar: 6, tidak seluruh Lembaga Amil Zakat memiliki Laporan Keuangan yang tersusun sesuai dengan standar akuntansi bagi organisasi nir laba. Informasi mengenai pengelolaan zakat, infaq dan shodaqoh dapat dengan mudah diakses oleh muzzaki memiliki nilai dibawah 10 (sangat mudah), atau dengan nilai rata-rata sebesar: 8 ,

3. Nilai Audit dibawah 10 (sudah teraudit) atau dengan nilai rata-rata sebesar 7, Laporan Keuangan Lembaga Amil Zakat sebagian besar telah diaudit oleh Kantor Akuntan Publik.

Tabel 6. Descriptive Statistics

\begin{tabular}{cccc}
\hline & Mean & Std. Deviation & $\mathbf{N}$ \\
\hline $\mathrm{Y}$ & 7,5000 & 1,08146 & 70 \\
$\mathrm{x} 1$ & 6,9357 & 1,29585 & 70 \\
$\mathrm{X} 2$ & 6,9238 & 1,32749 & 70 \\
\hline
\end{tabular}

Berdasarkan tabel 6. Statistik deskriptif menjelaskan bahwa rata-rata responden menjawab kuesioner untuk pertanyaan Variabel Dependen mengenai pengelolaan zakat, infaq dan shodaqoh adalah 7,500 atau rata-rata reponden menjawab pada poin 7-8 dengan standar deviasi 1,08146 dari jumlah data 70, dapat disimpulkan bahwa responden merasa puas dengan pengelolaan dana zakat, infaq dan shodaqoh pada Lembaga Amil Zakat dan merasa yakin, serta akan menyalurkannya melalui Lembaga Amil Zakat dibandingkan penyaluran langsung kepada mustahik, sampai pada akhirnya akan menyarankan kepada muzzaki lainnya untuk menyalurkan dananya melalui Lembaga Amil Zakat tertentu. 
Berdasarkan pada tabel 5. Statistik Deskriptif, menjelaskan bahwa rata-rata responden menjawab kuesioner untuk pertanyaan Variabel Independen X1 mengenai pengelolaan zakat, infaq dan shodaqoh secara amanah adalah 6,9357 atau rata-rata reponden menjawab pada poin 7 dengan standar deviasi 1,29585 dari jumlah data 70, dapat disimpulkan bahwa responden merasa bahwa pengelolaan dana zakat, infaq dan shodaqoh pada Lembaga Amil Zakat telah dilakukan secara tabligh dengan indikator bahwa informasi dilakukan secara terbuka, kemudahan akses data, telah melaporkan perolehan dana zakat dan memasukkan data pihak-pihak yang memberikan dana, memberikan informasi yang seimbang dan merata kepada masyarakat.

Berdasarkan pada tabel 6. Statistik Deskriptif, menjelaskan bahwa rata-rata responden menjawab kuesioner untuk pertanyaan Variabel Independen X1 mengenai pengelolaan zakat, infaq dan shodaqoh secara amanah adalah 6,9238 atau rata-rata reponden menjawab pada poin 7 dengan standar deviasi 1,327849 dari jumlah data 70, dapat disimpulkan bahwa responden merasa bahwa pengelolaan dana zakat, infaq dan shodaqoh pada Lembaga Amil Zakat telah dilakukan secara amanah dan bertanggungjawab dalam menyajikan, melaporkan dan mengungkapkan segala aktifitas kegiatan, Laporan Keuangan tersusun dengan standar akuntansi bagi organisasi nir laba dan Laporan Keuangan telah diaudit oleh Kantor Akuntan Publik.

\section{Uji Validitas}

Uji validitas pada penelitian ini ditujukan untuk mengukur dan menunjukkan tingkat kevalidan atau kesahihan suatu instrumen. Suatu instrumen dianggap valid apabila mampu mengukur korelasi antara variabel independen dan dependen. Dengan kata lain, mampu memperoleh data yang tepat dari variabel yang diteliti. Uji validitas dilakukan dengan korelasi Product Moment (Pearson) dengan hasil 0,682 atau lebih besar dari 0,364 sehingga data yang didapat dari penyebaran kuesioner dapat dikatakan valid dan dapat dilanjutkan ke proses pengolahan data penelitian selanjutnya.

Tabel 7. Uji Validitas (Pearson)

\begin{tabular}{llccc}
\hline & \multicolumn{2}{c}{ Y } & $\mathbf{x 1}$ & \multicolumn{2}{c}{ X2 } \\
\hline Pearson Correlation & Y & 1,000 &, 682 &, 656 \\
& X1 &, 682 & 1,000 &, 751 \\
Sig. (1-tailed) & X2 &, 656 &, 751 & 1,000 \\
& Y &. &, 000 &, 000 \\
& X1 &, 000 &, &, 000 \\
$\mathrm{~N}$ & $\mathrm{X} 2$ &, 000 &, 000 &. \\
& $\mathrm{Y}$ & 70 & 70 & 70 \\
& $\mathrm{X} 1$ & 70 & 70 & 70 \\
& $\mathrm{X} 2$ & 70 & 70 & 70 \\
\hline
\end{tabular}




\section{Uji Reliabilitas.}

Uji reliabilitas menunjukkan sejauh mana suatu hasil pengukur relatif konsisten walaupun diberikan kepada orang yang berbeda dengan pertanyaan yang sama. Pada uji reliabilitas dilakukan dengan menggunakan Cronbach aplikasi SPSS untuk mengetahui apakah pengukuran yang digunakan reliabel.

Tabel 8. Uji Reliability Statistics

\begin{tabular}{ccc}
\hline Cronbach's Alpha & $\begin{array}{c}\text { Cronbach's Alpha Based on } \\
\text { Standardized Items }\end{array}$ & N of Items \\
\hline, 871 & 873 & 3 \\
\hline
\end{tabular}

Uji reliabilitas diukur dengan menggunakan koefisien alpha (cronbach alpha) dari hasil perhitungan dengan menggunakan program statistik SPSS release 9.0. dengan $\alpha$ di atas 0,60 . Suatu instrumen penelitian dikatakan reliabel jika mempunyai nilai koefisien alpha (cronbach's alpha) di atas 0,60 (Sekaran, 1992; Cooper dan Emory, 1995).

Hasil uji reliabilitas yang tampak pada tabel 4.9 yaitu nilai cronbach's alpha sebesar 0,871 . Hasil tersebut menunjukkan bahwa kuesioner penelitian ini reliabel sebagai instrumen penelitian.

\section{Koefisien Korelasi}

Tabel 9. Correlations

\begin{tabular}{llccc}
\hline & & Y & X1 & X2 \\
\hline Pearson Correlation & Y & 1,000 &, 682 &, 656 \\
& x1 &, 682 & 1,000 &, 751 \\
Sig. (1-tailed) & X2 &, 656 &, 751 & 1,000 \\
& Y &. &, 000 &, 000 \\
& x1 &, 000 &. &, 000 \\
N & X2 &, 000 &, 000 &. \\
& Y & 70 & 70 & 70 \\
& x1 & 70 & 70 & 70 \\
& X2 & 70 & 70 & 70 \\
\hline
\end{tabular}

Berdasarkan tabel 9. variabel dependen Y memiliki korelasi/hubungan positif dan signifikan dengan variabel independen $\mathrm{x} 1$ dan $\mathrm{x} 2$, hal ini didukung dengan nilai probabilitas sebesar 0.000 atau kurang dari 0.05 , sehingga hipotesis diterima.

Besarnya korelasi/hubungan antara variabel dependen $\mathrm{Y}$ dengan variabel independen $\mathrm{x} 1$ adalah 0.682 , sedangkan besarnya korelasi/hubungan antara variabel dependen $\mathrm{Y}$ dengan variabel independen $\mathrm{x} 1$ adalah 0.682 . 
Tabel 10a. Variables Entered/Removed(b)

\begin{tabular}{cccc}
\hline Model & Variables Entered & Variables Removed & Method \\
\hline 1 & $\mathrm{X} 2, \mathrm{x} 1(\mathrm{a})$ &. & Enter \\
\hline
\end{tabular}

a All requested variables entered.

b Dependent Variable: Y

Tabel 10b. Model Summary(b)

\begin{tabular}{ccccc}
\hline Model & R & R Square & $\begin{array}{c}\text { Adjusted R } \\
\text { Square }\end{array}$ & $\begin{array}{c}\text { Std. Error of } \\
\text { the Estimate }\end{array}$ \\
\hline 1 &, $716(\mathrm{a})$ &, 513 &, 498 &, 76606
\end{tabular}

a Predictors: (Constant), X2, x1

b Dependent Variable:

Setelah dilakukan analisis menggunakan SPSS maka didapatkan nilai koefisien korelasi sebesar 0,716. Atau $\mathrm{R}=$ positif $(+1)$ sehingga hubungan antara variabel independen dengan variabel dependen sangat kuat. Dengan demikian dapat diartikan bahwa Tabligh dan Amanah memiliki pengaruh dan hubungan yang kuat dalam pengelolaan zakat, infaq dan shodaqoh pada Lembaga Amil Zakat di Surabaya.

\section{Koefisien Determinasi $\left(\mathbf{R}^{2}\right)$}

Koefisien determinasi merupakan cara yang digunakan untuk menjelaskan seberapa besar bariabel independent mempunyai kontribusi terhadap variabel dependen. Didalam hasil penelitian menggunakan SPSS dan dapat terlihat pada tabel 4.12. maka didapatkan nilai $\mathrm{R}^{2}$ adalah sebesar 0,513 , kontribusi variabel independen (x1 dan $\mathrm{x} 2$ ) terhadap variabel dependen (Y) adalah 51,3\% dimana pendekatan model yang dgunakan adalah tepat. Kurang sempurnanya nilai $\mathrm{R}^{2}$ (R Square) dikarenakan masih banyak variabel variabel independen lain selain faktor tabligh dan amanah atau faktor diluar tabligh dan amanah yang dapat mempengaruhi pengumpulan zakat, infaq dan shodaqoh pada Lembaga Amil Zakat di Surabaya, sehingga hal ini dapat dijadikan masukan bagi peneliti-peneliti selanjutnya. 


\section{Uji F}

Tabel 11. ANOVA(b)

\begin{tabular}{ccccccc}
\hline Model & & Sum of & \multicolumn{3}{c}{ Mean } \\
Squares & df & Square & F & Sig. \\
\hline 1 & Regression & 41,382 & 2 & 20,691 & 35,258 &, $000(\mathrm{a})$ \\
& Residual & 39,318 & 67 &, 587 & & \\
& Total & $\mathbf{8 0 , 7 0 0}$ & $\mathbf{6 9}$ & & & \\
\hline
\end{tabular}

a Predictors: (Constant), X2, $\mathrm{x} 1$

b Dependent Variable: Y

Uji ini digunakan untuk menguji pengaruh variabel-variabel independen terhadap variabel dependen secara bersama-sama. Bila $\mathrm{F}$ hitung memiliki tingkat signifikasi lebih rendah dari 0,05, maka dikatakan ada pengaruh signifikan. Dari hasil Uji F pada penelitian ini seperti tampak pada tabel 4.13 dengan nilai signifikan 0,000 atau dibawah 0,05. Maka Variabel independen yaitu Tabligh (x1) dan Amanah (x2) secara bersama-sama/simultan secara statistik signifikan mempengaruhi variabel dependen yaitu pengelolaan Zakat, Infaq dan Shodaqoh pada Lembaga Amil Zakat di Surabaya.

Uji t

Tabel 12. Coefficients(a)

\begin{tabular}{ccccccc}
\hline Model & \multicolumn{7}{c}{$\begin{array}{c}\text { Unstandardized } \\
\text { Coeficient }\end{array}$} & $\begin{array}{c}\text { Standardized } \\
\text { Coefficients }\end{array}$ & \\
\hline \multirow{4}{*}{1} & & B & Std. Error & Beta & T & Sig. \\
& Constant & 3,125 &, 529 & & 5,908 &, 000 \\
& X1 &, 363 &, 108 &, 435 & 3,362 &, 001 \\
& X2 &, 268 &, 105 &, 330 & 2,550 &, 013 \\
\hline
\end{tabular}

Uji ini digunakan menguji pengaruh variabel independen (Y) secara parsial terhadap variabel dependen yaitu variabel $\mathrm{x} 1$ dan $\mathrm{x} 2$ secara bersama-sama. Dari tabel 12. terlihat bahwa nilai $t$ untuk $x 1$ sebesar 3,362 atau lebih besar dari 2 sehingga secara statistik dapat dinilai bahwa variabel tabligh secara parsial signifikan mempengaruhi variabel $\mathrm{Y}$ yaitu pengumpulan zakat, infaq dan shodaqoh pada Lembaga Amil Zakat di Surabaya demikian pula nilai t untuk x2 sebesar 2,550 atau lebih besar dari 2 sehingga secara statistik dapat dinilai bahwa variabel amanah secara parsial signifikan mempengaruhi variabel $\mathrm{Y}$ yaitu pengumpulan zakat, infaq dan shodaqoh pada Lembaga Amil Zakat di Surabaya. 
Pada tabel 12. juga dapat dinilai tingkat signifikan dibawah 0,05 yaitu x1 dengan nilai signifikan sebesar 0,001 dan x2 dengan nilai signifikan sebesar 0,013 sehingga kedua variabel dependen (x1 dan $\mathrm{x} 2$ ) atau variabel tabligh dan amanah secara parsial signifikan mempengaruhi variabel independen $\mathrm{Y}$ yaitu pengumpulan zakat, infaq dan shodaqoh pada Lembaga Amil Zakat di Surabaya.

\section{Uji Asumsi klasik}

Multikolinieritas

Hasil uji multikolonieritas pada tabel 13 menunjukkan hasil perhitungan nilai tolerance menunjukkan bahwa tidak ada variabel independen yang memiliki nilai tolerance kurang dari 0,10 . Selain itu hasil perhitungan nilai varian inflation factor juga menunjukkan hal yang sama tidak ada satu variabel dependen yang menunjukkan nilai VIF lebih dari 10. Jadi dapat disimpulkan bahwa tidak ada multikolonieritas antar variabel independen dalam model regresi.

\section{Tabel 13. Multikolinieritas}

\begin{tabular}{|c|c|c|c|c|}
\hline \multirow{2}{*}{$\begin{array}{c}\text { Variabel } \\
\text { Independen }\end{array}$} & \multirow{2}{*}{$\begin{array}{c}\text { Variabel } \\
\text { Dependen }\end{array}$} & \multicolumn{2}{|c|}{ Hasil Pengujian } & \multirow[t]{2}{*}{ Keterangan } \\
\hline & & Tolerance & VIF & \\
\hline $\begin{array}{c}\text { Pengumpulan Zakat, } \\
\text { Infaq dan Shodaqoh } \\
\text { pada Lembaga Amil } \\
\text { Zakat di Surabaya }\end{array}$ & Tabligh & ,435 & 2,297 & $\begin{array}{c}\text { Tidak } \\
\text { Multikolonieritas }\end{array}$ \\
\hline $\begin{array}{c}\text { Pengumpulan Zakat, } \\
\text { Infaq dan Shodaqoh } \\
\text { pada Lembaga Amil } \\
\text { Zakat di Surabaya }\end{array}$ & Amanah & ,435 & 2,297 & $\begin{array}{c}\text { Tidak } \\
\text { Multikolonieritas }\end{array}$ \\
\hline
\end{tabular}




\section{Uji Normalitas}

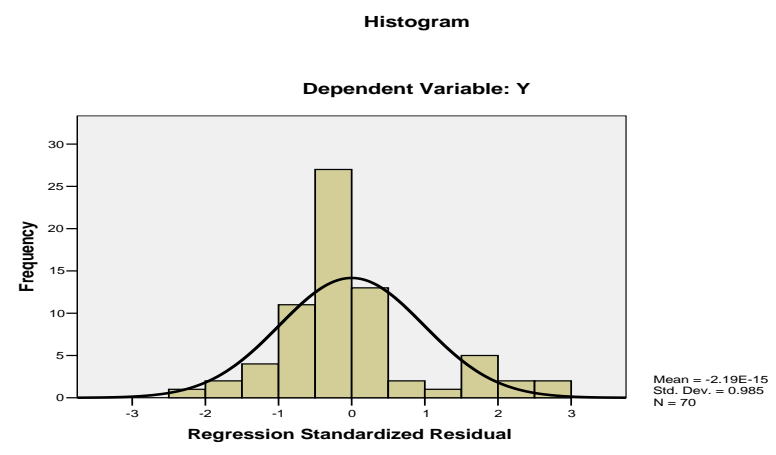

Normal P-P Plot of Regression Standardized Residual

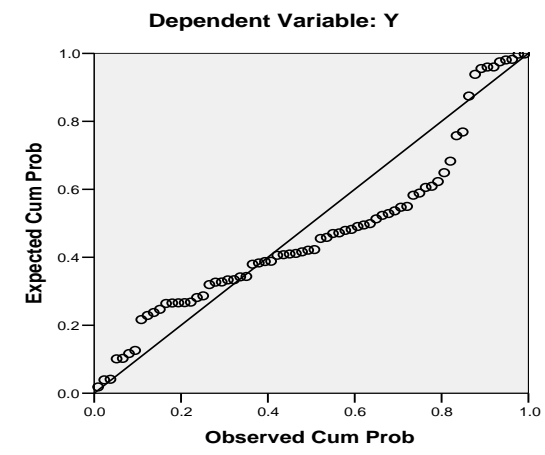

Grafik normal pola menunjukkan penyebaran titik-titik disekitar garis diagonal, dan mengikuti arah garis mengindikasikan bahwa model regresi memenuhi asumsi normalitas

\section{SIMPULAN DAN SARAN}

Simpulan

Berdasarkan analisis data diperoleh simpulan sebagai berikut:

a) Tabligh (Transparansi informasi) dan amanah (Akuntabilitas organisasi) secara bersama-sama mempengaruhi pengumpulan zakat, infaq dan shoadaqoh pada Lembaga Amil Zakat di Surabaya.

b) Tabligh (Transparansi informasi) berpengaruh positif terhadap pengumpulan zakat, infaq, dan shadaqah pada BAZ dan LAZ di Surabaya.

c) Amanah (Akuntabilitas organisasi) berpengaruh positif terhadap pengumpulan zakat, infaq, dan shadaqah pada BAZ dan LAZ di Surabaya. 


\section{Saran}

Berdasarkan simpulan yang diperoleh dari analisis data maka saran bagi LAZ sebagai berikut:

a) Dari sisi pengawasa terhadap dana Zakat, Infaq dan Shodaqoh yang dikelola oleh Lembaga Amil Zakat, Muzzaki kurang dapat melakukan pengawasan sehingga diharapkan pihak LAZ memberikan kemudahan dan keterbukaan pada muzaki untuk bisa melakukan pengawasan.

b) Dari sisi keseimbangan informasi antara manajemen dengan masyarakat Lembaga Amil Zakat kurang memberikan informasi yang seimbang sehingga diharapkan pihak LAZ dapat menyeimbangkan informasi yang diterima antara pihak manajemen dan masyarakat luas.

c) Rendahnya $\mathrm{R}$ Square yang hanya sebesar 51\%, sehingga sebenarnya pengumpulan zakat, infaq dan shodaqoh hanya sebesar $51 \%$ saja yang dipengaruhi oleh tabligh dan amanah, sedangkan sisanya dipengaruhi oleh faktorfaktor diluar variable tersebut sehingga masih terbuka lebar untuk dikembangkan penelitian dengan variabel yang berbeda. 


\section{DAFTAR PUSTAKA}

Adiwijaya, 2000, Akutansi Keuangan jilid 1, Semarang, Sultan Agung Press. Al-Qur'an dan Terjemahnya, yayasan Penyelenggara Penterjemah, 2001, jakarta Arif Mufradi, 2006, Akutansi dan Manajemen Zakat, Jakarta, kencana Chapra, M.Umer, 1985, Toward a Just System, The Islamic Fondation, London Farooq, Mohammad, The Challenge of Proverty and the Proverty of islamic economics

Hafidhuddin, Didin, 2005, Anda Bertanya Tentang Zakat, Infak, dan Sedekah Kami

Menjawab, Gema Insani, Jakarta

Harahap, Sofyan Syafitri, 2003, Teori akutansi, Jakarta, Raja Grafindo Persada

Heryani, Dahlia,2005, Studi Penerapan Akutansi Zakat Pada Lembaga Amil Zakat, Google.

Ikatan Akutansi Indonesia, 2007, Standar Akutansi Keuangan, Jakarta, Salemba Empat.

Irvan Abu Baker dan Charier, 2006, filantropi dan keadilan sosial, Jakarta.

Inayah,Gazi,2003, Teori Komperhensif Tentang Zakat dan Pajak, Tiara Wacana, Yogyakarta.

Kabir, Md, Positive Accounting Theory and Science, New Zew Zealand, Auckland University of Technology.

Leversque and McDougall, 1998, Organizational Behavior, New york, McGraw Hill

MS, Salman, Corporate Finance in an Interest Free Economicy, Karachi, University of East

Permono, Sjechul Hadi,1995, Pendayagunaan Zakat dalam Rangka Pembangunan Nasional, Persamaan dan Perbedaan dengan Pajak, Pustaka Firdaus, Jakarta.

Permono, Sjechul Hadi,2008, Formula Zakat Menuju Kesejahteraan sosial, Khalista, Surabaya.

Sudarsono, Heri, 2007, Bank dan Lembaga Keuangan Syariah, Ekonisia, Yogyakarta. 